Fall 2013

\title{
The Temporality of Modernist Life Writing in the Era of Transsexualism: Virginia Woolf's Orlando and Einar Wegener's Man Into Woman
}

Pamela L. Caughie

Loyola University Chicago, pcaughi@luc.edu

Follow this and additional works at: https://ecommons.luc.edu/english_facpubs

Part of the English Language and Literature Commons

\section{Recommended Citation}

Caughie, PL. "The temporality of modernist life writing in the era of transsexualism: Virginia Woolf's Orlando and Einar Wegener's man into woman" in Modern Fiction Studies 59(3), 2013.

This Article is brought to you for free and open access by the Faculty Publications and Other Works by Department at Loyola eCommons. It has been accepted for inclusion in English: Faculty Publications and Other Works by an authorized administrator of Loyola eCommons. For more information, please contact ecommons@luc.edu. cc) (i) $\ominus$

This work is licensed under a Creative Commons Attribution-Noncommercial-No Derivative Works 3.0 License. (c) Purdue Research Foundation by the Johns Hopkins University Press, 2013. 


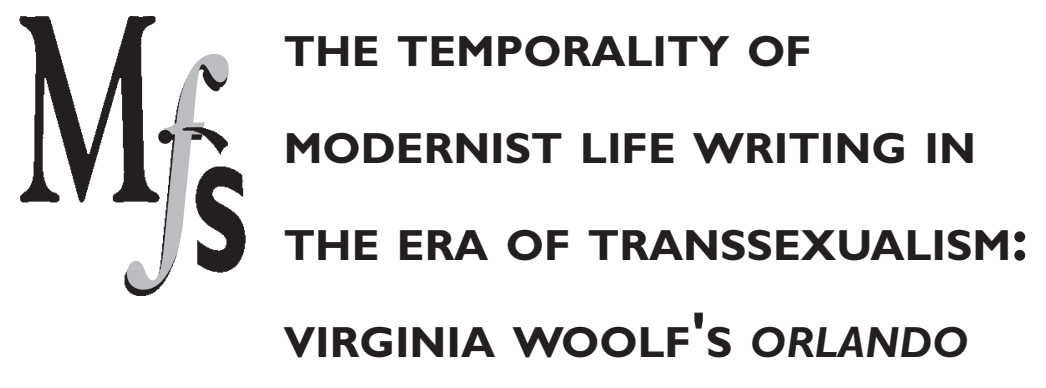

\author{
AND EINAR WEGENER'S MAN
}

INTO WOMAN

\title{
Pamela L. Caughie
}

Consider what immense forces society brings to play upon each of us, how that society changes from decade to decade . . . ; well, if we cannot analyse these invisible presences, we know very little of the subject of the memoir; and again how futile life writing becomes.

-Virginia Woolf, "A Sketch of the Past"

In a conversation with Bruno Latour, historian and philosopher of science Michel Serres provides a metaphor that captures modernist life writing's temporality. Our experience of time, says Serres, resembles a crumpled handkerchief rather than a flat plane, where the past folds in on the present, pressing on it at difference places, and the present folds in on the past, pressing on it from behind in that the present redacts our understanding of what the past has become (60). ${ }^{1}$ Virginia Woolf shares this understanding of the proximity of 
the present and the past in her classic life writing narrative, Orlando, as in her memoir, "A Sketch of the Past," begun in 1939, where she dates each reminiscence to include the present moment in which she writes as "a platform to stand upon" (75). In writing a life, and in reading life writing, one unavoidably encounters the past from some present vantage point, some immediate stimulus that revisions that past, and thus the present as the past's future, gathering up moments in time that resonate with the present moment. In this sense, Orlando's composition of "The Oak Tree" over three centuries is not fantastic, a temporal aberration, but emblematic of how writing and reading work. "The present when backed by the past," writes Woolf, "is a thousand times deeper than the present when it presses so close you can feel nothing else" ("Sketch" 98). Likewise, the past when backed by the present is far deeper, more yielding than when visited as a discrete period, as if only a moment in time.

In this essay, I read Woolf's 1928 mock biography, Orlando, whose eponymous protagonist changes from a man into a woman midway through her life, in relation to the discourse of transsexualism in the modernist era. In particular, I compare Orlando with the contemporaneous Man into Woman: An Authentic Record of a Change of Sex, the biography-memoir of Danish artist Einar Wegener, who, as Lili Elbe, can lay claim to the title of the first transsexual. Although transsexualism as we study it today emerged out of early-twentiethcentury scientific discoveries and technologies, such as synthetic hormones and advances in plastic surgery, it was also engendered by modernist aesthetics, formal innovations responding to and shaping a changing social discourse of sexuality and subjectivity. By focusing on the nexus of scientific experimentation with the real and aesthetic experimentation with representation as reciprocal cultural forms, I uphold the power of literature, not just the promise of science, to reshape notions of gender and identity in the modernist era. Insofar as it offers new ways to read sexual and gender identity as narrative, modernist aesthetics makes textual analysis as critical as cultural history to contemporary transgender studies. Instead of taking the transsexual as the subject of Woolf's novel, as many critics do, I take this figure as its object of thought, one that led Woolf to produce a model of modernist life writing in the era of transsexualism that I call a "transgenre."2

Orlando serves as the prototype of the transgenre, one that reconfigures in life writing narratives not only notions of gender but also of time, identity, history, and the very nature of writing and reading. Recently the French, for whom the word "genre" (gender) refers not to sexuality but to linguistics, have begun to use "transgenre" to translate the English "transgender." "Transgenre," then, when used 
in French, foregrounds linguistic differences and distinctions in works about gender. I adopt the French "transgenre" in English for narratives treating transgender lives that transfigure conventions of narrative diegesis. ${ }^{3}$ Transsexual life writing, as other scholars have noted, disrupts conventions of narrative logic by defying pronominal stability, temporal continuity, and natural progression. It thereby demands a new genre, a transnarrative. Woolf reached this insight in writing Orlando, remarking in her diary that she doubted she would write another novel after Orlando, that she would need another name for her fiction (Diary 3, 176). Transnarratives cross genres-for example, medical, psychological, judicial, journalistic, anthropological, philosophical, autobiographical, fictional-as in the case of Orlando with its generic mix of biography and fantasy, philosophy and literary history, poetry and prose. They cross-or more accurately, crisscross-temporal moments as the protagonist transitions in gender and in time. Of necessity, transnarratives emphasize the artifice of gender, even while maintaining its naturalness. The term "transgenre" extends Sandy Stone's provocative suggestion in her 1991 landmark essay, "The Empire Strikes Back," that transsexuals be considered "not as a class or problematic 'third gender,' but rather as a genre-a set of embodied texts whose potential for productive disruption of structured sexualities and spectra of desire has yet to be explored" (165). That potential has been explored by Virginia Woolf in Orlando.

Insofar as it reconceives the very concept and form of life writing, Orlando radically refigures the narrative of transsexualism presented in Lili Elbe's more conventional tale. Using transsexualism as an organizing metaphor in the construction of a life, as Woolf does in Orlando, produces a different understanding of temporality and of those "invisible presences" that society "brings to play on each of us" and that Woolf complains have "never been analysed in any of those Lives which I so much enjoy reading" ("Sketch" 80). Orlando breaks down arbitrary historical divisions, renews the past in the present, immerses us in time, dramatizes how life and literature acquire a shape, and a value, within multiple pasts and always in relation to a present moment. Woolf makes the art of prose fiction, specifically temporality and narration, central to identity. When in the early stages of writing Orlando Woolf was fascinated by a newspaper article about a young woman who became a man (Bell v. 2, 132), that moment provided not so much the subject for her fictionalized biography as the occasion for re-conceptualizing the subject of life writing. 


\section{Transsexualism in the Modernist Era}

The modern is a period, in fact, most likely to produce a work like Orlando.

-Suzanne Young, "The Unnatural Object of Modernist Aesthetics"

As gender historians and modernist scholars have noted, the modernist era witnessed tremendous change in concepts of sexual and gender identity. ${ }^{4}$ Psychoanalysts, sexologists, and endocrinologists challenged the sacrosanct nineteenth-century belief in sexual dimorphism in positing a universal bisexuality. ${ }^{5}$ Anthropologists wrote about the tradition of the man-woman, men dressing and living as women, in various cultures. The modern girl cut her hair, dressed in pants, smoked in public, and rode the subway, arousing anxiety about "masculine women and feminine men."6 Newspaper and later radio accounts of women living as men, and men as women, were widespread. The journal Urania was founded in the 1910s explicitly to resist distinct, and binary, sexual categories. ${ }^{7}$ When we consider the many modernist literary works that treat transsexualism and what we call today transgender, ${ }^{8}$ Woolf's comment "No age can ever have been as stridently sex-consciousness as our own" (A Room 99) that I once took as a profound insight into the modernist era seems a rather banal understatement.

Less noted among modernist scholars is that the term "transsexualism" was coined in 1923 (would that it were 1922!) by Magnus Hirschfeld, founder of the Institute for Sexual Science in Berlin, where the first transsexual surgeries were performed, a fact relevant to the changes noted above. In his article "The Intersexual Constitution," Hirschfeld coined "transsexualism" to describe the adoption of the gender role opposite to birth sex by men and women who held an unswerving conviction that they were assigned the wrong sex. Yet already in Transvestites, where Hirschfeld created the category of transvestism to distinguish cross-dressing from homosexuality, the lack of a single term to capture the various experiences of his subjects led him to describe, if not yet name, transsexuals. ${ }^{9}$ Despite such taxonomic efforts to distinguish categories of transvestite, transsexual, and homosexual, inversion, intersexuality, and bisexuaity, sexual categories were in flux in the modernist era. Confusion among them reigned then as it does now, with Hirschfeld himself conflating them at times.

When gender historians and modernist scholars caution us against imposing our contemporary notions of gender and sexuality on a previous era, they themselves impose a more coherent set of 
definitions on early-twentieth-century scientific and popular narratives than the literature supports. Historian Alison Oram, for example, warns scholars against asserting a transhistorical identity for the transsexual, "reading the confused category of the early twentiethcentury invert as evidence of a past transsexual subject" ("Crossdressing" 279). In "Fin de Siècle, Fin de Sexe: Transsexuality and the Death of History," Rita Felski cautions that metaphoric uses of transsexuality, such as those employed by postmodern and feminist theorists, elide historical differences in concepts of, and investments in, gender (150). Such caveats can prevent naïve readings and prove useful for scholarship, as, for example, when Brenda Helt says that the fact that bisexuality was not yet a sexual identity in the 1920s, that it referred to personality not sexual orientation, makes it useful as a textual strategy in Orlando (131). In point of fact, however, past usage of sexual terms was not stable. Even though many critics insist that the word queer, for example, which appears frequently in modernist literature, did not yet carry homosexual connotations, it was beginning to be sexualized in the modernist era. It is as difficult to say when the term transsexual achieved sufficient coherence and stability to be marked as distinct from present usage as it is to say precisely when a transsexual's transition from one sex to another begins and ends.

Such anxiety about imposing our present notions on past writings risks under-reading the present moment, the platform on which we stand, in reading the past. In guarding against the conflation of historical moments we may suppress their proximity. Confusion in terminology in modernists texts, whether Hirschfeld's or Woolf's, is not something to clear up in terms of our present knowledge but something to realize and negotiate in our readings of modernist-era writing and its social formations. As Gertrude Stein blandly reminds us in "How Writing is Written," "everybody is contemporary with his period" (488), a seemingly simple if not simplistic assertion that raises profound questions of what it means to read the past. To understand the modernist past in its contemporaneity, Stein suggests, it is not enough just to recapture that past as it was; one must also appreciate the modernist sense of time as synchronous, not linear. ${ }^{10}$ Historicizing cannot itself be a transhistorical act, flattening out different temporalities in reading across historical time. That is not time as a crumpled handkerchief but time as a sequence of discrete eras. A modernist reading of the past reads synchronically, across the folds of the handkerchief. Further, the metaphoric use of transsexuality is precisely one means by which to negotiate such narratives and their historical differences. Metaphors enable us to read sexual identity as a historically-specific narrative. ${ }^{11}$ Woolf's transsexual metaphorically 
links temporality (trans as movement) with sex and sexuality. Such metaphors do not elide the past but encode it in the writing of the present and future.

Reading across the folds of Hirschfeld's writings provides a deeper insight into what he means by transsexualism. In Transvestites Hirschfeld argues that it is a mistake to imagine male and female as two "fully separate entities," asserting that "the constantly present merging of both into one ... is the core for the genesis and substance of personality" (18). Yet in that work, Darryl Hill argues, Hirschfeld created a sexual category premised on a theory that disavowed sexual categories. Even a cursory reading of Transvestites, Hill argues, reveals not only that Hirschfeld's definition of transvestite differs from our own (someone who cross-dresses for sexual excitement) but also that in interpreting his source material, Hirschfeld ignored crucial aspects of his subjects' experiences, exposing tensions and contradictions between their stories and his reading of them (316). ${ }^{12}$ Hirschfeld's study shows, Hill concludes, what other historians of sexuality have found: namely, that his subjects resisted the definitions and interpretations imposed on them by medical science (318). Historians need to listen to, in George Chauncey's phrase, "the elusive evidence of the ordinary" (qtd. in Hill 319), Hill argues, not just read the works of the authorities.

Where Hirschfeld sought to distinguish transvestites from homosexuals "to remove legal and medical obstacles to sexual and gender variance" (Meyerowitz 21), Hill seeks to privilege personal narratives. Hirschfeld's study, as Hill notes, relies on published letters, news reports, case studies, interviews, and popular publications about cross-dressing men and women. If we were to read it as an example of a modernist transgenre, it would necessarily offer contradictory evidence and produce conflicting interpretations, working against any effort to establish the truth about transvestism, or transsexualism, whether that truth comes from medical science or personal narratives. The sexologist's or psychoanalyst's case study, as Michael Levenson notes, is itself a modernist experimental narrative form that offers a "new metaphysics of character, . . . an overlay of past and present" (83). Giving a name, transvestism, and later transsexualism, to such "elusive evidence" traced across various genres creates a generic distinction rather than a definitive category or a new sexual identity, as Hirschfeld is presumed to do. In other words-specifically Sandy Stone's-we can read the transvestite or transsexual in Hirschfeld's writing as a genre.

Missing in Hill's reading is any awareness of the subjects' conscious construction of their narratives to create the kinds of distinctions they, or their doctors, desire. If you want to be understood as a 
transsexual and not as a female impersonator, as one of Hirschfeld's subjects insists, then you must assume a certain subject position within narratives of desire and sexuality. Hirschfeld's notion of the "constantly present merging" of sex differences captures that sense of changing narrative position and need not be read as a new subject position. The discrepancy between the position the subject assumes in the narrative and the way s/he is positioned in Hirschfeld's reading and other source materials requires of us a different kind of reading, that is reading people the way many of us have learned to read characters, taking into account narrative conventions and narrative time, the temporal span of a story, and the historical and social contexts within which the narratives operate. Such a practice requires reading across genres rather than holding any one genre-the personal narrative, the medical treatise, the official biography-as authoritative. I am not suggesting that personal narratives should be discounted, as Stone says autobiographical accounts by transsexuals are often dismissed by the medical establishment (155); rather, personal accounts should be read as narratives.

What Hirschfeld faced in writing about sexual and gender experiences that defy conventional categories resembles what Orlando's biographer faces in trying to write about his elusive subject. Narrating the life of a subject who changes sex certainly taxes conventions of life writing, yet so do the minutiae of daily life that no single account can hope to capture. "The elusive evidence of the ordinary" describes perfectly the kind of details provided in so many modernist narratives. The typist scene in The Waste Land, Bloom's perambulations through Dublin in Ulysses, the detritus of everyday life that clutters Jacob's Room come to mind as famous examples. Orlando, like Jacob Flanders, is neither a traditional character presented through his actions in the world, the kind of biographical figure Woolf found objectionable, nor a modernist character presented through "the atoms as they fall" ("Modern Fiction" 155), the kind of impressionistic interiority that has long defined modernist fiction. The transsexual in Orlando is the narrative's organizing principle, not its subject. The "elusive evidence of the ordinary" in such modernist texts does not necessarily prove the authority (in this case, Hirschfeld) wrong, as Hill implies; instead, insofar as it characterizes the contemporaneity of modernist life writing, whether fiction or nonfiction, such evidence suggests a way of reading the modernist past commensurate with its terminological confusion and temporal conflations. In both his writings and in his life's work at his institute in Berlin, Hirschfeld was a modernist, constructing new narratives of embodiment and new metaphors of gender. ${ }^{13}$ 
In the 1920s Hirschfeld met Eugene Steinach, an Austrian physiologist who as early as 1912 had successfully transplanted ovaries into male guinea pigs, producing female sex characteristics in male mammals. Steinach's experiments paved the way for sexual reassignment surgery. Although Joanne Meyerowtiz identifies Dorchen Richter as "the first complete genital transformation" (19) at Hirschfeld's Institute, the most famous sex change was that of Einar Wegener, begun in 1930 and chronicled in Man into Woman. ${ }^{14}$ In Modernism, Technology and the Body, Tim Armstrong acknowledges that the desire to transform a man into a woman may seem at odds with Hirschfeld's argument for sexual intermediaries and gender ambiguity, offering the "experimental, clarificationary thrust of modern science" (167) as one explanation of this apparent contradiction. By reading Hirschfeld as a modernist, however, we might focus less on the scientific product of his experimentation than on the shaping of a new narrative. When used in such words as transvestite, transsexual, and transgender, "trans" connotes movement, and while these concepts are often read in terms of movement from one identity category to another, an understanding reinforced by the title of Wegener's memoir, such movement also works to defy fixed categories. "Trans" signifies the dynamics of identity and identification-the social, cultural, and psychological processes by which a subject comes to understand his or her identity in relation to others. ${ }^{15}$ It is this emphasis on the "constantly present merging" (Hirschfeld's phrase) of different sexes and different times, so prominent in Orlando, that is missing from Wegener's so-called authentic account, to which I now turn.

\section{Creating the First Transsexual}

Representation at its most magical, the transsexual body is perfected memory, inscribed with the "true" story of Adam and Eve as the ontological account of irreducible difference, an essential biography that is part of nature.

-Sandy Stone, "The Empire Strikes Back"

The memoir, Man into Woman, published shortly after the last in a series of four surgeries Einar Wegener underwent and after the public disclosure of the sex change, begins in Paris in 1930, shortly before Adreas Sparre (the name Wegener assumes in this fictionalized Lebensberichte) departs for Dresden to begin a series of operations that will bring Lili, his feminine persona, to life as Lili Elbe. Niels Hoyer (a pseudonym for Ernest Ludwig Jacobson), identified as Lili Elbe's biographer and the editor of Man into Woman, created 
the narrative based on his personal knowledge of Einar and his wife, Gerda Wegener (Grete Sparre in the memoir), material dictated by Wegener and later Lili Elbe, and Lili's diaries and letters. The story is narrated primarily from the perspective of Andreas and Lili (and briefly Grete's) in both third person (the heterodiegetic narrator is presumably Hoyer) and first person (in passages, such as chapter VI, where Andreas narrates his past life to friends), what Gérard Genette terms the homodiegetic, or more precisely, autodiegetic. ${ }^{16}$ At the memoir's end, in a letter to a friend, Lili discusses the pronominal dilemma that transsexual narratives confront: "Should I write a preface to the book, to explain why, when speaking of Andreas, I always use the third person, as in a novel? But, my dear friend, what other form of narrative could I have chosen?" (283). That is the key question for transsexual memoirs: How can an autodiegetic "I" refer to two differently sexed beings? Lili's solution, to write of Andreas in the third person "as in a novel," intimates the importance of the imagination and of narrative form to transsexual life writing.

As Armstrong has observed, Wegener's transformation into Lili, as narrated in the memoir, has less to do with the Steinach procedure than with fin-de-siècle art and literature in its progress from fantasy and art to medical intervention (Modernism, Technology 169). Wegener's wife, Gerda, also an artist, gained fame as an art deco illustrator in fashion magazines of the day, including Paris Vogue. In his wife's art studio, Wegener served as a cross-dressed model well before his surgery, adopting the persona of Lili. ${ }^{17}$ The story begins, then, in what Armstrong terms a "playful masquerade" (117); Wegener initially cross-dressed to substitute for his wife's client who missed an appointment, but then began to appear as Lili more and more frequently, eventually leaving the privacy of the studio to appear in nightclubs throughout Paris. When Grete tells Andreas that she feels as if she is creating the hypostatic Lili and not just the figure who appears on her canvas, she affirms Armstrong's comment that the narrative "reflects on the construction of gender as an artistic process" (Modernism, Technology 169). Lili herself refers to the surgical interventions that gave birth to her as the doctor's "art" (277). In other words, the first historical transsexual is as much a matter of art and artistry as of science.

In the memoir, Andreas becomes Lili psychologically, emotionally, even physically, long before the operations as he gradually moves from cross-dressing as a model to being his wife's female companion. Contemporary scholars such as Armstrong and Elizabeth Freeman have suggested that modernist interventions in the body, including sexual reassignment surgery, can be understood in terms of the "embodied thinking" (Bourdieu 474) that Pierre Bourdieu 
calls the habitus: "those complexes of gestures, postures and words ... which only have to be slipped into, like a theatrical costume, to awaken, by the evocative power of bodily mimesis, a universe of ready-made feelings and experiences." This bodily mimesis, says Armstrong, provides "a metaphorical basis for all understandings of social identification" (Modernism, Technology 7). In her introduction to the GLQ special issue on queer temporalities, Freeman invokes Bourdieu's habitus to explain how time makes bodies and subjects. "Queer theory has implicitly built on the concept of habitus with Judith Butler's model of gender performativity," she writes, "to which we owe the understanding that supposedly natural attributes of masculinity and femininity are the result of repetitions sedimenting over time" (160-61). Clearly Andreas exemplifies the "evocative power of bodily mimesis" insofar as the donning of a dress and the assumption of a certain posture are enough to make him accepted by all, including himself and Grete, as a separate being. More to the point, his shuttling back and forth between Lili and Andreas in the years leading up to the surgeries illustrates, as does Orlando, not just the repetitions "sedimenting over time" but the recursive nature of time in the process of gender formation.

Lili's emerging identity as an artistic and recursive process, however, soon gives way to the belief in an essential self trapped in an alien body, inaugurating the wrong body narrative that dominates transsexual memoirs to this day. The narrative ends up downplaying the performative effects of Andreas's masquerade and ultimately undercuts the iterative nature of gender identity asserted elsewhere in the narrative. In the end, the memoir adheres to a more conventional view of sexual difference. For Lili Elbe is literally born, in the language of this memoir, with the surgery. After the operations, she claims to be entirely different from Andreas in personality: he was "ingenious, sagacious, and interested in everything," Lili says; she is "a woman. A thoughtless, flighty, very superficially minded woman, fond of dress and fond of enjoyment" (235). The before-and-after handwriting samples included in every edition of Man into Woman, meant to authenticate the change from Andreas to Lili, reinforce this narrative of absolute difference, even though such evidence has been shown to be a fiction. ${ }^{18}$

Significantly, Lili acknowledges the necessary performance of femininity: "I had to demonstrate every day that I was a different creature from him [Andreas], that I was a woman" (235). Although Lili quickly adds that she was really this way, that her performance of femininity was not "merely farcical acting" (235), that she was not, as Hirschfeld's subjects also insist, a female impersonator, she also concedes that she must uphold the fiction of absolute difference to 
pass as a woman: "Other women could be ugly, could commit every possible crime. I, however, must be beautiful, must be immaculate, else I lose every right to be a woman" (236). "For women," as Orlando observes, "are not . . . obedient, chaste, scented, and exquisitely apparelled by nature" (156-57). Rather than pursue such an observation, however, Lili instead seeks evidence that the performance was unnecessary, that she is the real thing. For example, when two former acquaintances pass Lili in Copenhagen, her hometown, without recognizing her as Andreas, and compliment her legs, "she swallowed the remark with avidity, not only as a compliment, but as a hundred per cent recognition of her identity as a woman" (237). Is the reader supposed to forget that Andreas began modeling for Grete because of his legs?: "You really have very pretty woman's legs," Grete told Andreas when she first cajoled him into donning women's clothing (63).

In fact, the narrative strongly suggests femininity as performance more after the sex change than before, when the crossdressing protagonist was mistaken for a woman often and easily, and could flirt without demeaning herself, as Lili is criticized for doing by other patients at the woman's hospital where she undergoes her surgery. When the preoperative Andreas performs in a friend's ballet, costumed in "close-fitting tights, a bolero, and a wig of short curls" (97), he is mistaken for a girl impersonating a man. Although Andreas later interprets this experience as a sign that Lili, the alien being trapped in the wrong body, was emerging, the narrative presents it as a failed performance of masculinity: "Good God, man, you look impossible like that!" says a fellow actor (98). Indeed, it is as if the surgery has taken away Andreas's natural femininity. The postoperative Lili worries that she is ugly, an "improbable phenomenon" (246) whereas earlier the cross-dressing Andreas had no such worries about being taken as a fraud.

Despite the narrative's thrust that reveals the making of a woman through painting (both on canvas and with cosmetics), fashion, posture, and performance, what Liz Conor terms "techniques of appearing" (2), the narrative works hard to reinforce the dualistic distinctions it thus calls into question, to insist on the naturalness of gender over gender as artifice. ${ }^{19}$ When Lili considers suicide (as Andreas does), for example, she says if she were to perish that way, "everybody would be right in saying that what had happened to me had been contrary to Nature, an audacious challenge of the unnatural and the artificial to the natural and to Nature" (278). Yet modernist-era writing presents just such an audacious challenge. Had the narrative chosen to defend artifice, had it given the narrative perspective to Grete, the artist figure in this work, the one who 
brings Lili into being through her paint and her clothing, the memoir would have been the modernist autobiography Armstrong claims it is. Instead, the memoir subordinates art to the embodied (or wrongly embodied) experience that has come to signify transsexualism and ultimately adheres to the nineteenth-century narrative logic of natural progression. It is to uphold the view of her natural female self that Lili opts for a fourth operation to give her the capacity to bear children, a desire, and a procedure, that kills her.

\section{Time's Queer Force}

On all sides writers are attempting what they cannot achieve, are forcing the form they use to contain a meaning which is strange to it.

-Virginia Woolf, "The Narrow Bridge of Art"

Woolf's transsexual narrative makes the art and artifice of gender self-conscious. The story begins in Elizabethan England with Orlando as a young boy brandishing his sword at a Moor's head, and ends in the moment of its writing, the eleventh of October 1928, with Orlando as a thirty-something woman shopping at Marshall \& Snelgrove's. In this fantastic tale, subtitled a biography (which, to Woolf's amusement, led at least one bookstore to shelve it under that genre), the eponymous protagonist lives for over three centuries, changing somewhere in the seventeenth century from a man to a woman. Orlando has all the trappings of a biography-an index, photographs, and other authenticating documents, such as letters and lists, and a preface by the author, in which she thanks, among others, literary figures, living and dead, and the British Museum and Record Office. Throughout the narrative, the biographer-narrator reflects on the difficulty of writing a biography, especially for someone like Orlando who spends much of his/her time in solitude, thinking and writing. In this way the narrative keeps the focus on the writing itself as part and parcel of the subject's life.

Orlando shares a number of motifs and themes with other transsexual narratives, in addition to the requisite sex change. There is the synecdoche of the leg whereby a single appendage comes to signify sexual identity, both masculinity and femininity at different points in the narrative as in history. There are explicit references to contemporaneous theories of sexual identity (as in the clothes philosophy passage discussed below); heightened attention to pronouns (as in the first line of the novel: "He-for there could be no doubt of his sex" [13]); reflections on memory and the past as transfigured 
by sexual difference; and elements of melancholy and the macabre (though these are as much a homage to Sir Thomas Browne and the fin-de-siècle decadents as they are signifiers of the abject lives of sexual dissidents). But more important for understanding Woolf's transgenre as a model for life writing in the age of transsexualism are its differences from other transsexual narratives.

An obvious difference is the treatment of the sex change. In Orlando as in no other transnarrative, the sex change is instantaneous, "unanticipated" and "undesired," as Karen Kaivola notes (235), even though the narrative defers acknowledgment of the change through an elaborate masque figuring the three female virtues: Purity, Chastity, Modesty. That long digression mocks the notion of a sex change as a momentous and temporally specific event, as the clock striking October 11,1928 , in the last chapter mocks the historian's measurement of time, as if either sexes or eras were discrete units that followed one another in succession. The narrator's matter-of-fact account and the insouciance with which Orlando responds to the change present this "incredibly fantastic" event as, if not commonplace, at least not uncommon: ${ }^{20}$ "Orlando looked himself up and down in a long lookingglass, without showing any signs of discomposure, and went, presumably, to his bath" (138). The treatment of this extraordinary event, as Kaivola notes, extends "the particularity of Orlando to a more general human truth" (235) - the truth that "one's life is not confined to one's body," as Woolf writes in "A Sketch of the Past" (84), or to one body. Importantly, Orlando's life suggests that the transsexual's watchword might not be "I'm trapped in the wrong body" but "I'm sick to death of this particular self. I want another" (Orlando 308).

The homecoming scenes in these two narratives illustrate the protagonists' different attitudes. When Orlando returns to her ancestral home after the sex change, there is some initial confusion as the servants greeting her, "overcome with emotion," remark "Milord! Milady! Milady! Milord!" (169). Yet no one, the narrator observes, "showed an instant's suspicion that Orlando was not the Orlando they had known" (170). Overjoyed to be home, Orlando settles back in to his (now her) old routines and picks up her writing where he had left off. When Lili returns to the house in which Andreas had been born, she "recognized it, remotely and hazily" as if in a dream (241). Asked by her brother if she could remember incidents from their childhood, Lili "was always obliged to answer in the negative" (241; emphasis added). Is the obligation here to tell the truth, or to keep up the fiction of absolute difference? As if to make the break from Andreas absolute, Lili insists she has no desire to paint, and that abandonment of aesthetic desire may be one reason Lili's erotic desires go only one way, like the bridge she says she crosses in transitioning from 
man into woman. Orlando, in contrast, continues writing the poem she began as a young man throughout the novel, finishing it as a modern woman, welcoming desire "in whatever form it comes," she says, "and may there be more forms, and stranger" (294).

Initially Orlando, newly female, loves women, out of habit: "As all Orlando's loves had been women, now, through the culpable laggardry of the human frame to adapt itself to convention, though she herself was a woman, it was still a woman she loved" (161). Eventually the power of bodily mimesis, and the pressure of Victorian convention, compel her to love and marry a man, though one whose gender is as suspect as Orlando's. Even this acquiescence, though, is presented not just as a performance of femininity, and a subversive one at that, but as indispensable for her writing. Comparing her "obeisance to the spirit of her age" (265) to a traveler smuggling a box of cigars through customs, Orlando thinks:

She had just managed, by some dexterous deference to the spirit of the age, by putting on a ring and finding a man on a moor, by loving nature and being no satirist, cynic, or psychologist-any one of which goods would have been discovered at once-to pass its examination successfully. And she heaved a deep sigh of relief. ... . Orlando had so ordered it that she was in an extremely happy position; she need neither fight her age, nor submit to it; she was of it, yet remained herself. Now, therefore, she could write, and write she did. (266)

Here Woolf articulates her own strategy in this narrative, her ability to write freely about contraband topics, such as those that resulted in the censoring of Théophile Gautier and Radclyffe Hall, without resorting to the satiric impulse that saved Compton Mackenzie and Djuna Barnes. She does so by giving us a protagonist who is neither wrongly sexed nor tragically gendered.

Read in the context of its cultural moment, Orlando thematizes new concepts of sexual identity circulating in scientific discourses and popular culture. Lisa Carstens identifies the following passage from Orlando with Sir Henry Head's theory of the self as a reiteration of postures the body performs over time, a theory that anticipates Bourdieu's concept of the habitus: "The change of clothes had, some philosophers will say, much to do with it. Vain trifles as they seem . . . they change our view of the world and the world's view of us" (187). This belief is illustrated by the cross-dressing protagonist of Man into Woman, as Andreas finds the more time he spends as Lili the more she takes over his body. The next passage, however, contradicts this view, asserting that "Clothes are but the symbol of 
something hid deep beneath. It was a change in Orlando herself that dictated her choice of a woman's dress and a woman's sex" (188). Many contemporary memoirs by transsexuals espouse this notion that sexual difference is ontological; something "deep beneath" dictates the outward change. ${ }^{21}$ Lili Elbe eventually adopts this view.

But two sentences later, the narrator offers yet another view in the statement often quoted as Woolf's theory of androgyny: "For here again, we come to a dilemma. Different though the sexes are, they intermix. In every human being a vacillation from one sex to the other takes place, and often it is only the clothes that keep the male or female likeness, while underneath the sex is the very opposite of what is above" (189). This notion of a permanent bisexuality is the one articulated by Hirschfeld in Transvestites, a view that became dominant among sexologists in the 1920s. The novel is often said to uphold this androgynous concept of sexual identity. ${ }^{22}$ Yet more important than which theory of identity Woolf may hold is her capturing the coexistence of conflicting notions of sexual identity that vary not only among sexologists and writers, but even within any one writer's works.

In its very narrative form Orlando disrupts the sexual dimorphism theorists of transsexualism and transsexual narratives like Lili Elbe's so often fall back on. The metaphor of the bridge, prominent in transsexual narratives, appears in Lili's memoir when she imagines that she has "built a slender bridge across that abyss which separates man and woman" (270). For Woolf, the metaphor of the bridge applies to experiments in the writing, not on the body. The narrow bridge of art, the title of an essay Woolf published in August 1927 shortly before she began Orlando, signifies the passage to a new prose genre, one capable of presenting an affective equivalent of the modernist era's new reality, "an age," Woolf says, "when we are not fast anchored where we are" ("Narrow Bridge" 11). Who better to serve as an emblem of this age of the unmoored than the transsexual? Like Lili Elbe, Orlando articulates the dilemma of those who choose or are forced to change their sex. Yet she does so in terms that capture the sensate experience that characterizes the new genre Woolf envisions at this time, whether the new biography (the title of an essay she wrote the same month she began Orlando) or the new novel. This new genre "will differ from the novel as we know it now chiefly in that it will stand further back from life" ("Narrow Bridge" 18) dispensing with fiction's "fact-recording power," and resembling poetry in expressing "emotions toward such things as roses and nightingales, the dawn, the sunset, life, death, and fate" ("Narrow Bridge" 19).

The poetry of this new transgenre is evident in a scene from Orlando that appears in some form in nearly every transsexual mem- 
oir, where the protagonist must account for her or his past life as the other sex. Voyaging home from Turkey after the sex change and seeing the cliffs of England for the first time as a woman, Orlando remarks that "she would have been hard put to it to explain to Captain Bartolus ... that she, who now trembled on his arm, had been a Duke and an Ambassador" (162). Yet a passage that begins with the fact of the sex change ends with the sensate experience of life: "How explain to him that she, who had been lapped like a lily in folds of paduasoy, had. . . lain with loose women among treasure sacks in the holds of pirate ships on summer nights when the tulips were abloom and the bees buzzing off Wapping Old Stairs?" (162). For the transsexual who conceives the narrow bridge as a passage from one sex to the other, the past becomes a burden and a conundrum. In Orlando, that same conundrum devolves into a series of tactile, visual, and aural sensations that life writing must capture if we are to know the subject of the memoir. ${ }^{23}$ The problem Orlando considers is not just how to account for yourself when your present sex does not match your past, but how to capture the minutiae of everyday life left out of so much life writing.

The figure of the transsexual gives potency and urgency to life writing's ultimate dilemma: how to account for oneself? Lili chooses to account for herself in terms of absolute difference and narrative progression, presenting herself as a miserable creature trapped in the wrong body until freed by the magic of modern science. Orlando, in contrast, conceives herself in terms of the "seventy-six different times all ticking in the mind at once" and as many as "two thousand and fifty-two" selves "built up, one on top of another, as plates are piled on a waiter's hand" (308), at once juxtaposing different temporal moments and accelerating into the future, beyond the boundaries of any single life, in a memorable instance of modernist temporality. In the final chapter, one long meditation on time, the rapid changes of bodily sensations, memories and desires that compose the self at any one moment are figured through the wonder of modern technology: "the process of motoring fast out of London so much resembles the chopping up small of body and mind, which precedes unconsciousness and perhaps death itself that it is an open question in what sense Orlando can be said to have existed at the present moment" (307). The bridge Orlando crosses is "the narrow plank of the present" (299), that "raging torrent" of sights, sounds, objects and impressions that swirl around her as she motors through London. From the time the clock strikes the present moment, the narrative presents us with a "configuration" (Benjamin 262), in Benjamin's sense, of present and past: "'When I step out of doors-as I do now,' here she stepped on to the pavement of Oxford Street, 'What is it that I taste? Little 
herbs. I hear goat bells. I see mountains. Turkey? India? Persia?' Her eyes filled with tears" (305; emphasis added). Whereas Lili insists she is happy because she "was a creature without any past" (171), an awkward concession to make in a memoir but one that upholds the fiction of the narrow bridge she has crossed from man to woman, Orlando dramatizes the persistence of the past in the present, making narrative temporality crucial to identity. Orlando insists that writing and identity, textuality and sexuality, the grammatical and the gendered, are learned together.

The frequent changes in the narration's temporal pacing, the many pauses in the story, as when the biographer looks out of the window while Orando writes, the numerous anachronisms in the form of both analepsis and prolepsis, the thematizing of time-all serve to accentuate time's queer force:

Time, unfortunately, though it makes animals and vegetables bloom and fade with amazing punctuality has no such simple effect upon the mind of man. The mind of man, moreover, works with equal strangeness upon the body of time. An hour, once it lodges in the queer element of the human spirit, may be stretched to fifty or a hundred times its clock length. . . . It would be no exaggeration to say that [Orlando] would go out after breakfast a man of thirty and come home to dinner a man of fifty-five at least. Some weeks added a century to his age, others no more than three seconds at most. (98-99)

Why do critics remark that Orlando barely ages in nearly four centuries when the span between 16 and 36 is enormous? Like Walter Benjamin's "Theses on the Philosophy of History," Woolf's narrative suggests, in Freeman's words, "a potentially queer vision of how time wrinkles and folds as some minor feature of our own sexually impoverished present suddenly meets up with a richer past, or as the materials of a failed and forgotten project of the past find their uses now, in a future unimaginable in their time" (163). The transsexual in Orlando is a figure of such future embodiment. The centrality of writing in this narrative, the emphasis on metaphoric language and literary history and the explicit discussions of writing's difficulties, present life writing not as an account of a life lived, but as the deliberate shaping of a narrative of a life that might be lived, and livable. The modernist transgenre as represented by Orlando is not about being true to life in the factual sense but about the consequences for living of telling a different kind of story. Orlando reemplots (Hayden White's term) life writing by changing the value readers tend to attach to certain kinds of facts and events, such as treating a sex change as mundane and 
the seasonal alterations of nature as a miraculous transformation. In this way, Orlando provides not the transsexual's life but a different way to narrate that life, one that can be more life-sustaining than the avowedly true-to-life account of Lili Elbe.

Orlando's closing chapter gathers up specific moments in time, particular scenes, scents and objects, and folds them into the present moment. "The past," writes Elizabeth Grosz in The Nick of Time, "is always already contained in the present, not as its cause or its pattern but as its latency, its virtuality, its potential for being otherwise" (254-55). This sense of the past informs Woolf's novel. In the closing pages of Orlando, the "pressure of the present" is unrelenting-"Braced and strung up by the present moment she was also strangely afraid, as if every time the gulf of time gaped and let a second through some unknown danger might come with it" (321)until the narrative ends with the last stroke of midnight on the day Woolf finished the novel. The next stroke will take us into the future, the day after the writing stops.

\section{A Wrinkle in Time}

The transaction between a writer and the spirit of the age is one of infinite delicacy.

-Virginia Woolf, Orlando

Has anyone ever asked why Woolf makes her Vita-figure a transsexual? She wants to pay homage to Vita's aristocratic heritage, to acknowledge her bi-sexuality, to make her into a fantastic largerthan-life figure, but is a sex change necessary for that? What the sex change emphasizes is not transition from one thing to another but transformation over time. Gender in Orlando is a historically specific cultural process, a matter of literary forms and legal institutions, psychology and medicine, fashion and social customs. Woolf's point here anticipates Foucault's in The History of Sexuality: namely, that gender and sexuality are constructed over time through an array of institutions and discourses. Woolf happened to be constructing a life of Vita, an exceptional person in terms of sexuality and gender, at the moment when new scientific models of gender and a new vocabulary of sex and sexuality were being formed. Setting Vita's life in a fictional version of that emerging discourse produces the modernist transgenre that invites us to read across temporal moments.

By providing an account of the past in terms of what is to come and representing the future as if it had already occurred, Orlando is a proleptic narrative. Beyond imagining the physical transformation of 
a man into a woman that is not to become a reality for several more years, Orlando models a reading of the past with an eye toward the future that opens the possibility of a new form of life writing, a way of encountering what has not yet been, what has not yet entered the historical record. The transsexual in this novel becomes a fantastic figure of future forms of relationality and intimacy, of desire, happiness and pleasure. Having laid her parents' ghosts to rest in To the Lighthouse, and with that past its familial model of intimacy, Woolf creates in Orlando a new model of home, marriage, and companionship, one more in keeping with Vita's life as well as the transsexual's life, but that also opens up possibilities of affiliation and affection for any individual. The family in To the Lighthouse gives way to heritage in Orlando, and the house expands beyond the nuclear family and a few close friends to embrace a society of strangers. Orlando's relation to parents, husband and child are no more significant-indeed, with the exception of Shel, much less significant-than her relation to lovers, servants, dogs, trees, and objects. That the transsexual Jan Morris cites Orlando in her autobiography gives new meaning to Suzanne Raitt's insight that the novel's ending opens into the future, extending "the boundaries of who we are, and of who we might be" (qtd. in Taylor 215). The figure of the transsexual allows for a truer depiction of the genre called life writing, which by definition is about the multitude of ways of inhabiting time and space, than does the conventional single-sexed subject. The transsexual's life narrative essentially changes the definition of life writing itself.

To counter the misconception that Lili Elbe's memoir is the prototype of transsexual life writing, we need a narrative logic that can provide a different temporality of embodiment. This narrative logic, which we find in Orlando, is more in keeping with its time in its sense of time than in anything it says about sexological discourses of the day. For Orlando's temporality is as queer as its eponymous protagonist. In her book, In a Queer Time and Place, Judith (now Jack) Halberstam uses "queer" (1) to refer to modes of temporality outside the structure of reproductive and family time, of generational inheritance and capital accumulation-the very temporality Woolf exposes in Orlando. Halberstam, like Woolf, argues for changes in conceptions of narrative, not in order to get the story right, not to make the narrative match the body or the body match the narrative (as Jay Prosser argues transsexual narratives do)-that is, not in the name of the real or the authentic, but in order to disrupt our notions of the real and our investments in authenticity. ${ }^{24}$ As a fantasy, Orlando, in Halbertsam's words, refuses "to privilege the literal over the figurative" (87). It is the insistence on the factually correct over the imaginatively and emotionally true that mars many transnarra- 
tives. Rather than looking for literal transsexuals in the modernist past, then, we might look to modernist literature as offering new narratives of embodiment that enable new configurations of gender and sexual identity.

Reading in this way invites us to experience the transgenre's temporal logic. From the platform of our present moment overbrimming with trans terms, we can recognize the transsexual as a proleptic subject, already there in the past, but not yet there in language. Woolf foresaw this experience of ours when she wrote, in the final pages of the manuscript, "words have yet to be coined for the selves have never been numbered" (280). Orlando establishes the trajectory-or transjectory-of the transgenre, where temporality is synchronous and recursive, the future is before us, and behind. It is both of its time and ours.

\section{Notes}

1. Concerning Serres's notion of time in relation to presentism, see Gajowski. Walter Benjamin's historical materialism similarly conceives history as folded into different moments in time. Benjamin's concept of history as a "constellation" of past and present, not a fixed moment in time to be mined as a source of meaning for an event or artwork, captures the concept of temporality that informs Woolf's life writings.

2. The play on "gender" and "genre" informs other readings of Orlando, though the term "transgenre" appears in only one, Anna Ciecko's essay on Sally Potter's Orlando, to refer specifically to new filmic genres. For other essays that read Orlando in terms of contemporary gender and transgender theory, see Coffman, Craps, and Taylor; for readings that treat the relation between gender and genre in Orlando, see Boehm and Young.

3. Coined in the 1990s, "transgender" serves as an umbrella term that includes transsexualism, with or without surgical intervention, as well as cross-dressing and various practices defying conventional notions of gender.

4. Mary Evans dates this insight to feminist literary scholars of the 1970s and 1980s: "Collectively, these critics [Ann Douglas, Elaine Showalter, and Alice Jardine] argued that what occurred at the end of the nineteenth and the beginning of the twentieth centuries was a denaturalization of gender. Partly as a result of the intellectual influence of Freud and psychoanalysis, and partly because human experience began to be less immediately controlled by 'nature' and the 'natural', it began to be possible to disturb conventional assumptions about masculinity and femininity. Within this literary tradition the most important work was Virginia Woolf's Orlando . . ." (72-73). 
5. According to Brenda Helt, bisexuality at this time referred to personality, not sexual orientation. Sigmund Freud, Otto Weininger, and Havelock Ellis are among those who promoted a theory of bisexuality. Helt argues that the various understandings of this concept made bisexuality a "floating signifier" (135), its many meanings "reflected and propagated the conflation of concepts now understood as distinct: biological sex, gender, desire, sexual preference, sexual identity, and intellectual and artistic superiority" (136). The same might be said of "transvestite" and "transsexual" as Magnus Hirschfeld defined them.

6. This phrase comes from the title of a popular American song, "Masculine Women, Feminine Men," produced by Okeh Records in 1926, with words by Edgar Leslie and music by James V. Monaco. For more on these changes, see Caughie.

7. In 1916 British feminist Thomas Baty (also known as Irene Clyde) founded Urania, a journal that advocated for cross-gender identification and the dissolution of sexual categories. Baty, who would be considered transgender today, also founded the Aëthnic Union in 1912. See Oram, "Feminism" and "Cross-dressing." For newspaper accounts of transgender in the 1920s and 1930s, see Oram, Her Husband Was a Woman.

8. The list includes Sherwood Anderson's "The Man Who Became a Woman," the Tiresias episode in T. S. Eliot's The Waste Land, the Circe chapter of James Joyce's Ulysses, Willa Cather's One of Ours (all works from that emblematic year 1922), all cited by Michael North in Reading 1922, as well as Radclyffe Hall's The Well of Loneliness, and writings by Gertrude Stein, Ernest Hemingway, Djuna Barnes, Bryher, and Virginia Woolf, among others. As North writes, much modernist literature was concerned in some way with the reorientation of gender and "a more general transsexuality" (191-92).

9. According to Meyerowitz, as early as 1916 German sexologist Max Marcuse published an article on the "drive for sex transformation" (18), distinguishing this drive from inversion or cross-gender identification, which both Hirschfeld and Ellis referred to as transvestism. Meyerowtiz says Hirschfeld's transvestite is today's transsexual.

10. Stein's concept of time in this essay, as in "Composition as Explanation," is as important as her concept of writing. Stein's use of the continual present, influenced by William James's theory of time as a continual flow of present moments, arranges historical events and ideas to indicate their coincidence or coexistence. Such synchrony is evident in Woolf's biographical novels Jacob's Room and Orlando as well. As Armstrong writes, "Modernism works . . . with notions of temporality which overlap, collide, and register their own incompletion . . . the dynamization of temporality is one of the defining features of modernism" (Cultural History 9).

11. Fredric Jameson's imperative "always historicize" might itself be read as an implicit metaphor in which the tenor, the historical past, can only be implied. In responding to calls to historicize, we would do 
well to keep in mind Hayden White's conception of historical narrative as an extended metaphor.

12. Hill did not have access to Hirschfeld's sources (they were destroyed when the Nazis raided Hirschfeld's institute in 1933), an important contextual difference to keep in mind when comparing his and Hirschfeld's readings of the subjects' life narratives.

13. In suggesting we read Hirschfeld as a modernist writer, I support recent scholarship on the Weimar Republic that seeks the continuities between literary culture and the new sciences. See, for example, Veronika Fuechtner.

14. The original Danish title was Fra Mand til Kvinde (1931), translated into German as Ein mensch wechselt sein geschlecht (a man changes his sex), a title, Armstrong writes, "which suggests the origins of the story in masculine fantasy" (Modernism, Technology 281). In 1933 the English language translations preserved the Danish title. The full title is Man into Woman: An Authentic Record of a Change of Sex. The true story of the miraculous transformation of the Danish painter Einar Wegener (Andreas Sparre).

15. For more on this concept of identity in the modernist era, see Caughie.

16. Genette's use of "hetero" and "homo" to refer to the position of the narrating agent in relation to the story emphasizes the importance of narrative to notions of sexuality and transsexuality.

17. The earliest photograph of Wegener cross-dressing as Lili appears in the German edition, Ein Mensch Wechselt Sein Geschlecht: Eine Lebensbeichte, dated Paris 1918.

18. Commenting on the handwriting, Stone says such an example "requires the reader to forget that orthography is an acquired skill" (157). Voice, another example of the dramatic change from man into woman offered by the narrative, is a trained muscle and does not suddenly alter following surgical intervention. "[N]one of this could have happened," Stone writes, which explains why clinics like Stanford's disregard such autobiographical accounts.

19. Norman Haire's authenticating preface reveals a similar ambivalence. Modern sexology, Haire writes, has "led to the conclusion that the hundred-per-cent male and the hundred-per-cent female are theoretical types which do not exist in reality" (ix). Yet later he refers to a man in Berlin who had his male organs removed and took injections of ovarian extract but, three years later, was unhappy for not yet becoming "completely a woman" (xi), as if a complete woman were something one could be in reality, not just theoretically.

20. In his introduction to Man into Woman, sexologist Haire refers to Wegener's story as "incredibly fantastic" (v).

21. Carstens argues that this passage expresses Woolf's belief in a core, if multiple, self (42). The insistence that the protagonist has no choice runs through narratives of sexual dissidents, such as in Foucault's 
Herculine Barbin, The Well of Loneliness, Man into Woman, and Boylan's She's Not There.

22. Woolf uses the more familiar concept of androgyny rather than the newly coined transsexualism. These concepts were in flux at the time. Kari Weil in Androgyny and the Denial of Difference, distinguishes between the androgyne as an "aesthetic ideal," or "cultural conceit," and the hermaphrodite as the physical condition (11). Yet Earl Lind (also known as Ralph Werther) in Autobiography of an Androgyne (1918) uses "androgyne" (19) for the lived identity, the actual physical and psychic condition, and sees the hermaphrodite as the aesthetic ideal (19-20).

23. As Catherine Neale Parke points out, Orlando conveys to readers the sense of what it felt like-physically, emotionally, intellectually, spiritually - to be Orlando "at precise moments of her male and female lives" (72). "The felt sense of living more than one life" comes not from the change of sex, I would argue, but from a change in emphasis in modernist life writing.

24. In Second Skins, Jay Prosser argues that surgery and hormones allow the transsexual to create a narrative about the body that enables the transsexual to become a subject, albeit one that is subject to binary notions of gender. Telling a coherent story about one's experiences as a transsexual is the first step toward transitioning to a new body. In this sense, the body comes to match the narrative, the narrative the body.

\section{Works Cited}

Armstrong, Tim. Modernism: A Cultural History. Cambridge: Polity, 2005. - Modernism, Technology and the Body: A Cultural Study. Cambridge: Cambridge UP, 1998.

Bell, Anne Olivier, ed. The Diary of Virginia Woolf. 5 vols. New York: Harcourt, 1980.

Bell, Quentin. Virginia Woolf: A Biography. New York: Harcourt, 1972.

Benjamin, Walter. "Theses on the Philosophy of History." 1940. Illuminations. Ed. Hannah Arendt. Trans. Harry Zohn. New York: Schockent, 1969.

Boehm, Beth. "Fact, Fiction, and Metafiction: Blurred Gen(d)res in Orlando and A Room of One's Own." Journal of Narrative Technique 22.3 (1992): 191-204.

Bourdieu, Pierre. Distinction: A Social Critique of the Judgement of Taste. Trans. Richard Nice. Cambridge: Harvard UP, 1984.

Carstens, Lisa. "The Science of Sex and the Art of Self-Materializing in Orlando." In Virginia Woolf Out of Bounds: Selected Papers from the Tenth Annual Conference on Virginia Woolf. Ed. Jessica Berman and Jane Goldman. New York: Pace UP, 2001. 39-45. 
Caughie, Pamela. "Passing as Modernism." Modernism/modernity 12.3 (2005): 385-406.

Ciecko, Anne. "Transgeder, Transgenre, and the Transnational: Sally Potter's Orlando." Velvet Light Trap 41 (1998): 19-34.

Coffman, Chris. "Virginia Woolf's Orlando and the Resonances of Trans Studies." Genders 51 (2010). n. pag. Web. 20 Jan. 2012.

Conor, Liz. The Spectacular Modern Woman: Feminine Visibility in the 1920s. Indianapolis: Indiana UP, 2004.

Craps, Stef. "How to Do Things with Gender: Transgenderism in Virginia Woolf's Orlando." Image into Identity: Constructing and Assigning Identity in a Culture of Modernity. Ed. Michael Wintle. New York: Amsterdam, 2006. 175-90.

Evans, Mary. Gender and Social Theory. Philadelphia: Open UP, 2003.

Felski, Rita. "Fin de Siècle, Fin de Sexe: Transsexuality and the Death of History." Doing Time: Feminist Theory and Postmodern Culture. New York: New York UP, 2000. 137-53.

Freeman, Elizabeth. "Introduction." Queer Temporalities. Spec. issue of GLQ: A Journal of Lesbian and Gay Studies 13.2-3 (2007): 159-76. Project Muse. Web. 20 Jan. 2012.

Fuechtner, Veronika. Berlin Psychoanalytic: Psychoanalysis and Culture in Weimar Republic Germany and Beyond. Berkeley: U of California P, 2011.

Gajowski, Evelyn. "Beyond Historicism: Presentism, Subjectivity, Politics." Literature Compass, 7/8 (2010): 674-91. Wiley Online Library. Web. 21 Feb. 2012.

Genette, Gérard. Narrative Discourse: An Essay on Method. Trans. Jane E. Lewin. Ithaca: Cornell UP, 1972.

Grosz, Elizabeth. The Nick of Time: Politics, Evolution, and the Untimely. Durham: Duke UP, 2004.

Halberstam, Judith. In a Queer Time and Place: Transgender Bodies, Subcultural Lives. New York: New York UP, 2005.

Haire, Norman. Introduction. Man into Woman: An Authentic Record of a Change of Sex. Ed. Neils Hoyer. Trans. H. J. Stenning. New York: E. P. Dutton, 1933. v-xii.

Helt, Brenda. "Passionate Debates on 'Odious Subjects': Bisexuality and Virginia Woolf's Opposition to Theories of Androgyny and Sexual Identity." Twentieth-Century Literature 56.2 (2010): 131-67. Ebsco. Web. 21 Jan. 2012.

Hill, Darryl B. "Sexuality and Gender in Hirschfeld's Die Transvestiten: A Case of 'The Elusive Evidence of the Ordinary.'" Journal of the History of Sexuality 14.3 (2005). 316-32.

Hirschfeld, Magnus. Transvestites: The Erotic Drive to Cross Dress. Trans. Michael A. Lombardi-Nash. Buffalo, NY: Prometheus, 1991.

Hoyer, Niels, ed. Man into Woman: An Authentic Record of a Change of Sex. Trans. H. J. Stenning. New York: E. P. Dutton, 1933.

Kaivola, Karen. "Revisiting Woolf's Representations of Androgyny." Tulsa Studies in Women's Literature 18.2 (1999): 235-61. JSTOR. Web. 25 Jan. 2012.

Levenson, Michael. Modernism. New Haven: Yale UP, 2011.

Meyerowitz, Joanne. How Sex Changed: A History of Transsexuality in the United States. Cambridge: Harvard UP, 2002. 
North, Michael. Reading 1922: A Return to the Scene of the Modern. New York: Oxford UP, 1999.

Oram, Alison. "Cross-dressing and Transgender." Palgrave Advances in the Modern History of Sexuality. Ed. H. G. Cocks and Matt Houlbrook. New York: Palgrave Macmillan, 2006.

- "Feminism, Androgyny and Love Between Women in Urania, 1916-1940." Media History 7.1 (2001). 57-70. Ebsco. Web. 25 Jan. 2012.

. Her Husband was a Woman! Women's Gender-crossing in Modern British Popular Culture. New York: Routledge, 2007.

Parke, Catherine Neale. Biography: Writing Lives. New York: Routledge, 2002.

Serres, Michel, with Bruno Latour. Conversations on Science, Culture, and Time. Trans. Roxanne Lapidus. Ann Arbor: U of Michigan P, 1995.

Stein, Gertrude. "How Writing is Written." The Gender of Modernism: A Critical Anthology. Ed. Bonnie Kime Scott. Bloomington: Indiana UP, 1990. 488-95.

Stone, Sandy. "The Empire Strikes Back: A Posttranssexual Manifesto." Camera Obscura 2.29 (1992): 150-76.

Taylor, Melanie. "True Stories: Orlando, Life-Writing and Transgender Narrative."Modernist Sexualities. Ed. Hugh Stevens. Manchester: Manchester UP, 2000. 202-18.

Weil, Kari. Androgyny and the Denial of Difference. Charlottesville: $U$ of Virginia P, 1992.

Werther, Ralph. Autobiography of an Androgyne. 1918. New Brunswick: Rutgers UP, 2008.

White, Hayden. "The Historical Text as Literary Artifact." The Norton Anthology of Theory and Criticism. 2nd ed. Ed. Vincent B. Leitch. New York, 2010. 1536-53.

Woolf, Virginia. The Diary of Virginia Woolf. 5 vols. Ed. Anne Oliver Bell. New York: Harcourt, 1980.

_. "Modern Fiction." 1919. The Common Reader: First Series. New York: Harcourt, 1925. 150-58.

_. "The Narrow Bridge of Art." 1927. Granite and Rainbow. New York: Harcourt, 1958. 11-23.

. Orlando: A Biography. 1928. New York: Harcourt, 1956.

- A Room of One's Own. 1929. New York: Harcourt , 1981.

_. "A Sketch of the Past." Moments of Being. 2nd ed. Ed. Jeanne Schulkind. New York: Harvest, 1985.

Young, Suzanne. "The Unnatural Object of Modernist Aesthetics: Artifice in Virginia Woolf's Orlando." Unmanning Modernism: Gendered Rereadings. Ed. Elizabeth Jane Harrison. Knoxville: $U$ of Tennessee P, 1997: 168-87. 